IZA DP No. 9324

The Affordable Care Act and the Growth of Involuntary Part-Time Employment

William E. Even

David A. Macpherson

September 2015 


\title{
The Affordable Care Act and the Growth of Involuntary Part-Time Employment
}

\author{
William E. Even \\ Miami University \\ and IZA \\ David A. Macpherson \\ Trinity University \\ and IZA
}
Discussion Paper No. 9324
September 2015

\author{
IZA \\ P.O. Box 7240 \\ 53072 Bonn \\ Germany \\ Phone: +49-228-3894-0 \\ Fax: +49-228-3894-180 \\ E-mail: iza@iza.org
}

Any opinions expressed here are those of the author(s) and not those of IZA. Research published in this series may include views on policy, but the institute itself takes no institutional policy positions. The IZA research network is committed to the IZA Guiding Principles of Research Integrity.

The Institute for the Study of Labor (IZA) in Bonn is a local and virtual international research center and a place of communication between science, politics and business. IZA is an independent nonprofit organization supported by Deutsche Post Foundation. The center is associated with the University of Bonn and offers a stimulating research environment through its international network, workshops and conferences, data service, project support, research visits and doctoral program. IZA engages in (i) original and internationally competitive research in all fields of labor economics, (ii) development of policy concepts, and (iii) dissemination of research results and concepts to the interested public.

IZA Discussion Papers often represent preliminary work and are circulated to encourage discussion. Citation of such a paper should account for its provisional character. A revised version may be available directly from the author. 
IZA Discussion Paper No. 9324

September 2015

\section{ABSTRACT}

\section{The Affordable Care Act and the Growth of Involuntary Part-Time Employment ${ }^{*}$}

This study tests whether the employer mandate under the Affordable Care Act (ACA) increased involuntary part-time (IPT) employment. Using data from the Current Population Survey between 1994 and 2014, we find that IPT employment in 2014 was higher than predicted based on economic conditions and the composition of jobs and workers in the labor market. More importantly, using difference-in-difference methods, we find that the increase in the probability of IPT employment since 2010 was greatest in the industries and occupations where workers were most likely to be affected by the mandate. We also show that there has been virtually no change in the probability of IPT employment where the number of workers affected by the mandate was small. We estimate that approximately 1 million additional workers between the ages of 19 and 64 are in IPT employment as a result of the ACA employer mandate.

JEL Classification: J22, J23, J32, J33, H25

Keywords: Affordable Care Act, involuntary part-time employment, employer mandate, health insurance

Corresponding author:

David A. Macpherson

Department of Economics

Trinity University

San Antonio, TX 78212

USA

E-mail: David.Macpherson@trinity.edu

\footnotetext{
${ }^{*}$ We thank Barry Hirsch, Julie Hotchkiss, Melinda Pitts, Aaron Yelowitz, and seminar participants at the Federal Bank of Reserve of Atlanta, University of Kentucky, and the Western Economic Association meetings for helpful comments and suggestions.
} 


\section{Introduction.}

At its passage, the 2010 Affordable Care Act (ACA) required that firms with 50 or more employees provide health insurance for their full-time workers or be subjected to penalties beginning in 2014. Many analysts argue that the law creates incentives for large firms to shift from full-time to part-time workers to avoid the penalties and the cost of providing health insurance.

While numerous news reports claim that firms are shifting to part-time work because of the ACA, no study of nationally representative data estimates whether the effects are quantitatively or statistically significant. While several researchers claim that the fraction of part-time workers rose sharply during the recession and remains above pre-recession levels, there is disagreement about why the number remains so high. Some believe that the threat of the ACA reduced employers’ willingness to hire full-time workers during the recovery. Others believe that the high level of part-time work is an aftermath of the recession and structural changes in the labor market unrelated to the ACA.

This paper attempts to sort out the effect of the ACA from cyclical or other structural changes in the labor market. To isolate the effect of the ACA, we use regression analysis to control for economic conditions, the industrial and occupational composition of the work force, and worker characteristics. We also use difference-in-difference methods that compare the rate of growth in part-time work among groups of workers that should be differentially affected by the law.

\section{Background.}

While ACA penalties were initially scheduled to take effect in 2014, the implementation dates and the group of affected workers changed over time. Table 1 summarizes some of these key dates. In July 2013, the administration announced that the implementation date for employer penalties would be pushed back to 2015. In February 2014, final regulations were published providing additional transition relief for mid-sized employers (50-99 employees) 
pushing their implementation date back to 2016. Transition relief was also provided for large employers $(100+)$ by reducing the minimum coverage rate to 70 percent of employees in 2015 and deferring the implementation of the 95 percent coverage rate until 2016. Although the implementation date was pushed back, some employers were making adjustments to avoid the penalties detailed in the new law as early as 2012. For example, Investor's Business Daily collected reports of workers' hours being reduced to avoid the ACA penalties from over 450 employers, with some reports filed as early as 2011.

In order to understand how employers could adjust their work force to avoid ACA penalties, we provide a brief review of the penalties and mandate. With initial passage of the ACA, “applicable large employers” would be assessed an "Employer Shared Responsibility” (ESR) penalty if they did not provide “minimal essential coverage” for their full-time employees and dependents at an "affordable price." A firm is considered an "applicable large employer" (ALE) if, based upon employment in the prior year, it employed an average of at least 50 fulltime equivalent employees (FTEs). Any worker averaging at least 30 hours per week (or 130 hours per month) is counted as one FTE. For part-time workers averaging less than 30 hours per week, total weekly hours of all part-time workers are divided by 30 to calculate FTEs (or monthly hours by 130). For example, if an employer has 40 employees who each work more than 30 hours per week and 60 part-time employees who each average 10 hours per week, total FTEs would be $40+(600 / 30)=60$ FTEs. $^{1} \quad$ Any employer with less than 50 FTEs is not an ALE and is exempt from ESR penalties.

An employer's insurance plan provides minimal essential coverage if the plan covers at least 60 percent of expected health care costs. The plan is deemed affordable if the employee's cost of coverage does not exceed 9.5\% of the employee's household income. Since employers may not know their worker's household income, they can instead rely on one of three safe harbors for determining the maximum cost for affordable coverage. ${ }^{2}$

If any of an ALE's full-time employees purchase health care in the private market and receive a federal premium subsidy, the employer may be subject to an ESR penalty. To be

\footnotetext{
${ }^{1}$ There is a seasonal worker exception exempting employers that average more than 50 full-time workers for 120 days or less during a year.

2 The three safe-harbors define affordability based on either the worker's wages reported on form W2, the worker's rate of pay at the beginning of the period, or the federal poverty line for a single individual in the relevant calendar year.
} 
eligible for a premium subsidy, a worker's income must be less than $400 \%$ of the federal poverty level, and the worker cannot have access to minimal essential health insurance coverage that is affordable through the workplace. Given the federal poverty lines in 2014, this implies that workers with one household member would be eligible for a subsidy if they earned less than \$46,680 annually; a worker from a household with four members would be eligible if the household earned less than $\$ 95,400$.

If a full-time ALE employee receives a federal subsidy, the employer could be assessed an ESR penalty. The size of the penalty depends on whether the firm provides affordable and minimal essential coverage to at least $95 \%$ of its full-time workers. If the firm meets this requirement, the penalty is $\$ 3,000$ per full-time worker receiving a subsidy, but no more than $\$ 2,000$ times the number of full-time employees less 30. If an ALE provides coverage to fewer than $95 \%$ of its full-time workers, its penalty will be $\$ 2,000$ per full-time employee (minus up to 30).

When the initial ESR penalties were scheduled to begin in the 2014 calendar year, the number of employees and their full-time status were determined by the number of employees and their work hours in 2013. ${ }^{3}$ As a result, if a firm wished to reduce exposure to ESR penalties that started in 2014, it would have to make adjustments during 2013. Moreover, while transition relief pushed the implementation of the ESR payments back to 2015, firms that made the adjustments in the first half of 2013 may have kept them in place knowing that with implementation in 2015, exposure to ESR penalties would be determined by 2014 employment levels.

In February 2014, the starting date for ESR payments was pushed back to 2016 for employers with between 50 and 99 employees. Some of these employers may have initiated adjustments in work hours for their employees prior to 2014, but the delay may have slowed these firms' responses to meeting the ACA guidelines.

\footnotetext{
${ }^{3}$ To determine the number of employees and their classification as a full- or part-time worker, each firm had to define three time periods: the measurement period, and the subsequent administrative and stability periods. To determine whether a firm was an "applicable large employer" in 2014, it would use a measurement period of between three and 12 months in the prior calendar year to determine which employees were full-time and part-time. Beginning in 2014, any continuing worker who was classified as a full-time worker during the measurement period must be treated as a full-time worker for the "stability period." In subsequent years, the firm could define a measurement period followed by an "administrative period," which would allow the firm to determine those workers classified as full-time for the subsequent stability period.
} 
There are a few ways that an ALE could reduce exposure to ESR penalties. First, the firm could provide affordable coverage to its full-time workers. According to data provided by the Kaiser Family Foundation, in 2012 the average premium for employer-based health insurance in the United States was \$5,384. ${ }^{4}$ For a full-time worker (2,000 hours per year), this is equivalent to an hourly wage increase of \$2.69. The cost would be higher for older workers and would vary across the states.

Firms increasing coverage for their full-time workers might try to shift the cost to the newly covered workers, requiring that employees pay a large share of the cost. If the firm is to avoid ESR penalties, however, the firm cannot require a worker eligible for a subsidy (i.e. those with household income below 400 percent of the poverty line) to contribute more than 9.5\% of household income for the insurance. Thus, for example, if a full-time worker (40 hours per week, 50 weeks per year) earned \$10 per hour (\$20,000 per year) and had no other household income, the firm could not require that the worker contribute more than $\$ 1,900$ for the health insurance. On the other hand, if the worker earned \$25 per hour, the firm could require the worker to contribute $\$ 4,750$ per year for the plan and shift most of the cost to the employee. Since employers are less able to shift the cost of adding coverage to low-wage workers, they will have a greater incentive to find ways to avoid the mandate for them.

If an ALE is unable to shift the cost of the health insurance to the worker by requiring that the employee pay a large share of the premiums, it could instead cut the worker's hourly wage. For example, if a worker previously earned \$10 per hour and received no health insurance, rather than require the worker to pay the equivalent of \$2 per hour for the health insurance (which would violate the rule on affordability), the firm could cut the worker's wage by $\$ 2$ per hour and require no employee contribution. This strategy is not feasible if the wage cut would put the worker's compensation below the minimum wage. Cutting the hourly rate would also limit a firm's ability to attract low-wage workers who place minimal value on the health insurance.

In sum, providing coverage is costly, and firms have incentives to shift the cost of the new coverage to workers by requiring employee contributions or cutting wages. Since such strategies are least effective for low-wage workers, employers are motivated to find alternative means to avoid the coverage requirement for low-wage employees. Several such strategies are

\footnotetext{
${ }^{4}$ http://kff.org/other/state-indicator/single-coverage/
} 
available. First, firms with close to 50 FTE employees could try to keep below 50 and escape exposure entirely. Employers could accomplish this by reducing the number of full-time employees while increasing hours worked per employee. For example, a firm with 40 employees who average 50 hours per week would be exempt whereas a firm with 50 employees who average 40 hours per week would not be exempt. Alternatively, a firm could keep its FTEs below the limit of 50 by hiring independent contractors or hiring temporary workers.

Second, a firm could reduce the size of the penalty and the cost of providing affordable coverage by shifting from full-time to part-time ( $<30$ hours) workers. Failing to provide parttime workers with coverage does not result in a penalty. Also, because a firm can compute a worker's full-time status by averaging hours worked over as many as 12 months, hiring shortterm employees would reduce the number of workers that must be provided coverage.

While the threat of ESR penalties created incentives for large firms to switch to part-time employment, in a 2014 report, the Congressional Budget Office (CBO) emphasized the impact of the health insurance subsidies on the supply side of the labor market. Mulligan (2014) provides a detailed analysis of the subsidy formula and concludes that, with the health insurance subsidies, millions of workers working a part-time schedule could yield more disposable income than a full-time schedule. In fact, the Congressional Budget Office (2014) estimated that the ACA subsidies will reduce the number of full-time-equivalent (FTE) employees by about 2.0 million by 2017. The CBO projects that virtually all of the reduction will be due to workers wanting to reduce hours or drop out of the labor market entirely because of the new health insurance subsidies.

When there is an increase in part-time employment from the supply side, the expectation is that the number of workers who are working part-time voluntarily would rise. On the other hand, if there is an increase in the demand for part-time workers (perhaps due to the ACA mandate), some workers with full-time jobs may be forced to accept a part-time job involuntarily. As Ehrenberg and Smith (1988) note, a smaller number of workers who prefer voluntary part-time employment could increase the number who are forced into part-time work. As an example, if the number of workers who prefer part-time work decreases, then employers may respond by cutting back on the hours of full-time workers. For example, teenagers have been a major source of part-time workers, and as teenage employment rates have dropped, some employers may cut hours for workers who prefer full-time jobs. 
Several studies have examined recent trends in part-time employment. Several of these studies focus on differential trends in voluntary (VPT) and involuntary part-time (IPT) employment. The Bureau of Labor Statistics defines IPT workers as those who work part-time, would prefer a full-time job, but are unable to find a full-time job because of economic conditions. VPT workers have part-time jobs but do not want a full-time job, or are unable to take a full-time job because of personal reasons (e.g. schooling, family responsibilities, phased retirement).

Valletta and Bengali (2013) point out that voluntary part-time work has been trending down over the past few decades and was largely unchanged during the Great Recession. On the other hand, Valletta and List (2015) point out that IPT employment rose sharply during the Great Recession and has dropped slowly since the recovery. Their analysis suggests that cyclical factors played an important role in the rapid rise in IPT work during the Great Recession, but structural factors have also been important. Structural factors that may have led to increases in IPT employment include employment shifts toward service industries that make greater use of part-time workers (e.g., wholesale trade and leisure and hospitality sectors) as well as demographic changes in the labor market resulting in fewer workers preferring part-time work. The high level of IPT work since the Great Recession is also documented by Cajner, Mawhirter, Nekarda, and Ratner (2014), and Canon et al. (2014). These studies also show that the growth of the service industry contributed to increases in IPT employment. ${ }^{5}$

Overall, there is a good deal of evidence that IPT employment has remained unexpectedly high since the Great Recession. The existing research attributes the persistently high levels of IPT employment to a combination of cyclical and structural factors. While numerous media reports document how employers are switching to part-time workers to avoid the pending ACA penalties, there are only a few studies that specifically address the role of the ACA.

Garrett and Kaestner (2015) use 2000-2014 Current Population Survey data to test whether the health insurance subsidies and expansion of Medicaid have had negative supply side effects. Their empirical analysis finds virtually no adverse effect of either the Medicaid expansion or ACA policies on labor force participation, employment, or usual hours worked per

\footnotetext{
${ }^{5}$ Yellen (2014) also discusses the potential role of a rising share of employment in the service sector as a potential explanation for increases in part-time employment.
} 
week. They do, however, report a modest increase in part-time employment (less than 30 hours per week). Their research does not, however, distinguish between VPT and IPT employment. Also, while their analysis of the effects of the Medicaid expansion make use of a difference-indifference (DD) approach that compares rates of change in part-time employment in treated and non-treated states, their analysis of the effect of the ACA overall does not use a DD approach. As a result, any factors that might cause part-time employment to rise or fall over time for all workers cannot be differenced out.

Mathur, Slavov and Strain (2015) also use 2008-2014 CPS data to examine the effect of the ACA mandate on part-time work. They do not distinguish between VPT and IPT work and examine the effect of the mandate on the ratio of people working 25-29 hours versus 31-35 hours. The effect of the mandate is based on a DD methodology that compares the change in the ratio after 2010 for a treatment and a control group. They consider three treatment groups defined on the basis of occupation, industry, or wage and find no evidence that the ratio of workers in the 25-29 versus 31-35 hour grew faster in the treatment versus control groups. They conclude that the ACA has not caused employers to switch to part-time work.

ADP Research Institute (2015) notes that a survey of employers in 2014 found that 38 percent of respondents said they would adjust employee hours based on the ACA employer mandate. On the other hand, they find no change between 2013 and 2014 in the distribution of hours worked. They admit, however, that changes in economic conditions may be offsetting the effect of the ACA on part-time work.

Dillender, Heinrich, and Houseman (2015) examine trends in VPT and IPT work separately and report that only IPT employment remains above pre-recession levels. They also note that IPT work has remained especially high in industries where large numbers of workers are likely to be affected by the employer mandate - retail trade, and accommodation and food services. In contrast, IPT employment has essentially returned to pre-recession levels in manufacturing where it may be more difficult to avoid the mandate. While the evidence is consistent with the ACA employer mandate causing an increase in IPT employment, it does not compare trends across all industries or occupations and does not provide a specific estimate of the change in IPT that might be attributed to the ACA mandate.

Overall, the extant literature finds that part-time work (particularly involuntary) remains higher than predicted after the Great Recession. There is no research that we are aware of that 
finds a strong link between the ACA and increases in part-time work. Our research will show such a link. Our work differs from the earlier work in two important ways. First, we focus on the effect of the ACA on IPT work. As discussed above, if the ACA drives up employer demand for part-time workers, many of the new part-time jobs will be held involuntarily. Second, we use DD methods that compare the rate of growth in IPT employment across workers according to how likely they are to be affected by the mandate. Prior studies have not used this same type of DD methodology to isolate the effect of the ACA from the effect of overall economic conditions.

\section{Data and Empirical Methods.}

To investigate the effects of the ACA on IPT employment, we use data from the Current Population Survey (CPS). The monthly survey has the requisite information on hours worked, earnings, and worker characteristics. The major shortcoming of the monthly survey is that it does not routinely collect information on firm size or health insurance coverage. However, the March Annual Demographic Supplements to the CPS provide firm size and health insurance information. Unfortunately, prior to 2011, the firm size categories do not allow us to precisely distinguish firms above and below 50 employees. As a result, we are forced to rely on a cut-off of 100 employees for a time-consistent definition of the firms that are most likely to be affected by the ACA. Even this definition is not perfect because the March data on firm size is based on the number of employees rather than the number of FTEs as defined by the ACA. The primary hypothesis we wish to test is that the threat of the ESR penalties established by the ACA caused large employers to shift from full-time to part-time workers and an increase in the fraction of workers with IPT jobs. The challenge is sorting out the effect of the business cycle from the ACA.

To examine the trend in part-time work, we use the monthly CPS data to compute the annual average of the percentage of workers aged 19-64 that are in VPT and IPT employment. We exclude workers aged 65 and over because they are eligible for Medicare and not eligible for a health insurance subsidy. We exclude 16-18 year olds since many of them are in school and would not work enough weeks in the year to be classified as a full-time work even if they worked 40 hours in a summer job. We also restrict our sample to wage and salary workers since 
self-employed workers are not directly affected by the mandate. Finally, we exclude workers residing in Massachusetts and Hawaii because these states had employer mandates prior to passage of the ACA. We also exclude workers from the District of Columbia due to a lack of data on economic conditions.

Consistent with the BLS definition of IPT (or "part-time for economic conditions), we define IPT workers as those who are working less than 30 hours per week, want a full-time job, but are working part-time because of either slack work or unfavorable business conditions, an inability to find full-time work, or seasonal declines in demand. ${ }^{6}$

In an attempt to determine whether the state of the economy or structural changes in the labor market are responsible for recent trends in part-time employment, we estimate a linear probability model for each type of part-time employment using the data from 1994-2009. The regression includes controls for state economic conditions (the unemployment rate and coincident and leading economic indicators), ${ }^{7}$ the worker's industry and occupation, ${ }^{8}$ month of year, and a wide range of personal characteristics that influence a worker's preference for parttime employment. ${ }^{9}$ We estimate the regressions separately for workers with less than a college degree (less than 16 years of education) and for those with 16 or more years. ${ }^{10}$

Using the regression results for the 1994-2009 sample, we generate a prediction of the probability of part-time employment for each worker and use sample weights to average across all workers in a given year to obtain an estimate of the percent of part-time workers in that year. We then generate out-of-sample forecasts of the percent of part-time workers from 2010-2014. Comparing the forecast with the actual data reveals whether the trend in the two types of PT

\footnotetext{
${ }^{6}$ It is important to note, however, that BLS tabulations of part-time work are based on a work week of less than 35 hours whereas we use a cut-off of 30 hours since that is the relevant cut-off for the ACA employer mandate. In 2014, reducing the cut-off for IPT employment from 35 to 30 hours per week reduces the number of IPT workers by approximately one-third.

${ }^{7}$ The coincident and leading economic indicators came from Federal Reserve Bank of Philadelphia: http://www.phil.frb.org/research-and-data/regional-economy/indexes/coincident/ and http://www.phil.frb.org/research-and-data/regional-economy/indexes/leading/

${ }^{8}$ The models include controls for 13 major occupations and 22 major industries.

${ }^{9}$ The personal characteristics include state (48 categories); age (5 categories); race (3 categories); female, marital status ( 3 categories); female interacted with marital status ( 2 categories); education ( 6 categories); and female interacted with number of children aged 0 to 5 and aged 6 to 17 (4 categories).

${ }^{10}$ In an earlier version of the paper, we split the sample according to whether workers had a high-school degree. Our overall estimates of the change in part-time employment were similar to those reported here, but subsequent analysis revealed that the group of workers with some college was more similar in terms of part-time work trends than those in the group of workers with at least a bachelor's degree.
} 
employment since 2010 can be explained by economic conditions or by changes in the composition of workers or jobs in the economy.

The actual and predicted trends for the two types of PT employment are presented separately by education group in figures 1 and 2 . A couple of points are notable. First, the cyclical behavior of VPT and IPT employment differ sharply. While VPT was relatively stable during the Great Recession, IPT rose sharply. Second, since the Great Recession, the actual level of VPT employment has been at or below predictions based on the 1994-2009 data. In 2014, the actual level of VPT employment was 44,000 above its predicted level for the low education group, and 1.11 million below the prediction for the high education group. Finally, since the Great Recession, IPT employment has remained above predicted levels for both education groups. The excess of actual relative to the predicted levels of IPT employment is 573,000 and 461,000, respectively, for the low and high education groups.

Since the out-of-sample forecast error could be sensitive to the period chosen to estimate the regression model, we also considered regression models with samples starting in 1994 but ending in 2007 or 2011. While the difference between actual and predicted levels of PT employment changed slightly, the above patterns persist. That is, in all three sample periods considered, IPT employment in 2014 was substantially higher than predicted for both education groups; VPT employment was very close to predicted levels for the low education group and substantially below predicted levels for the high education group.

While this evidence implies that IPT employment in the past few years was significantly higher than predicted based on economic conditions and labor market structure, this does not necessarily indicate that the ACA is responsible. Other structural changes in the economy that are not controlled for in our regression model might explain a broad-based shift of employer preferences toward part-time workers.

To assess whether the ACA is an important reason for the rise in IPT employment, we employ a DD methodology. In particular, we test whether the increase in IPT employment since the onset of the ACA is greatest in industries or occupations where the fraction of workers possibly affected by the mandate is greatest. To test whether this is the case, we first use March CPS data from 2003-2007 to estimate the fraction of workers in each industry most likely to be 
affected by the ACA penalties. ${ }^{11}$ Namely, for each 3-digit industry, we calculate the proportion of workers who are employed at firms with 100 or more workers, work 30 or more hours per week, and do not have health insurance. ${ }^{12}$ We choose the 2003-2007 sample period to exclude the effects of the Great Recession on IPT work and to get an estimate of the percent affected under more normal economic conditions. The fraction affected is computed separately for our low and high education groupings. We merge this estimate of the fraction affected by 3-digit industry to the monthly CPS data spanning 1994-2014, and estimate the following regression:

(1) $y_{i t}=\alpha_{0}+$ affect $_{i} * \alpha_{1}+\sum_{s=2010}^{2014}\left(d_{\mathbf{s}} * \theta_{1 s}+\right.$ affect $\left._{i} * d_{\mathbf{s}} * \theta_{2 s}\right)+X_{i t} \beta+\epsilon_{i t}$

where $y_{i t}$ is a dummy where the worker is IPT or VPT; affect is $_{\mathrm{i}}$ the estimated fraction of workers affected by the mandate in individual i's industry, $\mathrm{d}_{\mathrm{s}}$ is a dummy that equals one if $\mathrm{t}=\mathrm{s}$, $X_{i t}$ represent the same set of control variables used in our earlier regression analysis of part-time employment, and $\alpha_{0}, \alpha_{1}, \beta$, and $\theta_{1 s}, \theta_{2 s}$ are coefficients to be estimated. In the above regression model, any change in the probability of PT employment in 2010-2014 relative to the 1994-2009 base period that is uniform across industries would be captured by $\theta_{1 s}$. Changes in the probability of a particular type of PT employment that vary across workers because the percent affected varies across industry is captured by $\theta_{2 s}$.

This regression specification allows a "difference-in-difference” type estimate of the impact of the ACA. Essentially, the identification of the ACA effect is achieved by comparing the growth rate in part-time employment for workers in industries with varying fractions of workers affected by the ACA. For example, the increase in the probability of PT employment

\footnotetext{
${ }^{11}$ To match the proportion affected from the 2003 to 2007 March Current Population Survey to the monthly 19942014 Current Population Survey data, all 3-digit industry and occupation codes were cross-walked into 1990 3-digit industry and occupation codes. The 1994 to 2002 monthly Current Population Survey data used 1990 codes, and no conversion was necessary. The 3-digit industry and occupation codes changed in 2003. Relatively minor revisions in occupation codes were adopted beginning in 2011, with further revisions in May 2012 (very small occupations were collapsed into larger ones). Minor changes to the industry codes started in 2009. All of the 3-digit industry and occupation codes were converted into their 2000 Census industry and occupation equivalents. These Census 2000 codes were converted into Census 1990 industry and occupation equivalents using the cross-walks contained in U.S. Census Bureau (2003). 1990 Census industries and occupations with less than 500 observations in the 1994-2014 sample for each of the two education groups were collapsed into the largest 3-digit industry or occupation within its detailed industry (52) or detailed occupation (46). This affected less than 0.5 percent of workers in the sample.

${ }^{12}$ We exclude observations with imputed industry, firm size, occupation, weekly hours, employer health insurance coverage, class of worker, weeks worked, or age. The weights are adjusted to account for deletions using the approach outlined in Bollinger and Hirsch (2006).
} 
in 2014 that is not explained by the control variables for an industry with no workers affected is $\theta_{1,2014}$. For a worker employed in an industry with all workers affected (affect=1), the increase in the probability would be $\theta_{1,2014}+\theta_{2,2014}$. The "diff-in-diff" estimate of the impact of the ACA in 2014 is therefore $\theta_{2,2014}$.

As a test for robustness, we repeat the method described above using 3-digit occupation instead of industry to estimate the proportion affected. Since the proportion affected is an estimated regressor, we use a two-step method to bootstrap the standard errors that mimics the data generation process. ${ }^{13}$

Figure 3 presents histograms of the proportion of workers affected across 3-digit occupations by education group. In the low education group, 16.0 percent of the workers are likely to be affected by the ACA employer mandate (i.e., employed at a large firm, working 30 or more hours per week, and without employer provided health insurance). In the high education group, 11.4 percent are identified as potentially affected. While the percent affected is higher for those without a college degree, a surprisingly large share of those with a college degree are in the potentially affected group.

The histogram illustrates substantial variation in the percent affected across the 3-digit industries. It is this variation in the fraction affected that we use to identify the effect of the ACA mandate.

In table 2, we present estimates of linear probability models for VPT and IPT for the regression specified in (1), without the interaction terms between the fraction affected and the year dummies. The regression includes the same list of controls as the earlier regression used to forecast VPT and IPT for 2010-2014 in figure 1. The models are estimated separately for both education groups. The standard errors are corrected for clustering by state.

The regression results imply that weaker economic conditions (i.e., a higher state-specific unemployment rate or a lower coincident index) increase both VPT and IPT. On the other hand, prospects of an improving economy (a higher state-specific leading indicator) lead to increases in

\footnotetext{
${ }^{13}$ In the first step, we randomly sample with replacement within group (industry or occupation) to capture the variation in the estimate of proportion of workers affected by industry. In the second stage, we randomly sample different groups with replacement and estimate the regression. We repeat the process 200 times and compute the standard error of the 200 estimated coefficients.
} 
both VPT and IPT. ${ }^{14}$ While we do not present coefficients for all the other control variables, it is worth noting that there is statistically significant variation in the probability of VPT and IPT across groups formed by age, education, race, marital status, industry, and occupation. Hence, both demographic and structural changes in the economy can lead to changes in both IPT and VPT. Also, some of the control variables have opposite effects on the probability of VPT and IPT. The heterogeneity in the effects across the types of part-time employment make a strong case for examining IPT separately from VPT. For example, IPT is more likely among less educated workers, and VPT is more likely among more educated workers.

The estimated year effects are consistent with the graphs in figures 1 and 2, and also provide a sense of the statistical significance of the patterns observed there. The estimated year effects illustrate that the probability of IPT employment is higher in 2014 than the base period (1994-2009) and that the difference is statistically significant at the .01 level for both education groups. Moreover, the size of the coefficients on the year dummies more than doubled between 2010 and 2014 in the low education group, and doubled for the high education group. The hypothesis that the probability of IPT employment is equal in 2010 and 2014 is rejected at the .01 level for both education groups. For VPT, the coefficients point to stable or declining VPT employment since 2010 for both education groups.

While the above comparisons are consistent with the hypothesis that the ACA contributes to increased IPT employment beyond predictions based on economic conditions and worker/job characteristics, other unobserved factors may be responsible. A stronger test relies on the difference-in-difference approach that includes the 2010-2014 year dummies interacted with the estimate of the fraction of a worker's industry or occupation that would be impacted by the ACA mandate. These regressions are presented in table 3.The t-statistics in the regression model are based on standard errors estimated by bootstrapping 200 times to adjust for estimation of the fraction affected in the first stage by industry (occupation) and by correcting for clustering of residuals by industry (occupation).

For a hypothetical industry or occupation with no workers affected by the ACA, the coefficients on the year dummies in table 3 reveal how the probability of IPT has changed since the base period. These coefficients reveal no evidence of the probability of IPT rising over time

\footnotetext{
${ }^{14}$ A sample of studies that examine the factors that influence the probability of part-time employment includes Ehrenberg et al. (1988), Euwals and Hogerbrugge (2006), and Barrett and Doiron (2001).
} 
for workers in industries or occupations not affected by the mandate. In fact, for industries/occupations without any affected workers, the model implies that the probability of IPT is lower in the 2010-2014 period than in the reference period, though the results is statistically significant only for the low education group. This implies that the growth in IPT employment is concentrated in the industries and occupations where workers are most likely to be affected by the ACA mandate.

The coefficients on the interaction terms between the year dummies and the proportion affected reveal that the change in IPT relative to the base period differs across workers according to the percent that are likely to be affected by the ACA. For workers without a college degree, the coefficient on the interaction term in 2014 is positive and statistically significant at the .01 level, regardless of whether the fraction affected is measured by industry or occupation. While the interaction term is also positive in 2010, the coefficients on the interaction terms rose sharply over the last five years of the sample and more than doubled in size. Moreover, the null hypothesis that the coefficients on the interaction terms are equal in 2010 and 2014 is strongly rejected. This implies that for workers without a college degree, IPT's probability grew most rapidly for those employed in industries or occupations with a large share of workers that would be affected by the ACA. ${ }^{15}$

To provide some sense of the magnitude of the effects of the ACA on IPT employment, we compare the growth in IPT employment across occupations with a high and low fraction of workers affected. For the low education group, the average worker is an occupation where the proportion of workers affected by the ACA is 0.16. The standard deviation of the fraction affected is .063. Compared to the base period, the probability of IPT employment in 2014 grew .017 more for a worker in an occupation with a high fraction affected (one standard deviation above the mean) than in an occupation with a low fraction affected (one standard deviation below the mean). While this may seem like a relatively small difference in the probability of IPT employment, only 3.5 percent of the low education group is in IPT

\footnotetext{
${ }^{15}$ One potential issue in the data is that respondents frequently round their answers when reporting hours worked. This is particularly true for 40 hours per week (see, for example, Welch 1997). To see if our results are sensitive to this heaping of hours responses, we re-estimated all the regressions with all those who report exactly 30 hours excluded from both the March CPS and the monthly CPS. The results are only slightly changed (see Appendix Table A1). All subsequent analysis ignores the issue with heaping of hours reports.
} 
employment in 2014. Consequently, a 1.7 percentage point difference in the probability of IPT employment is quite large relative to the base.

For workers with a college degree, the results are not as clear. While the coefficients on the interaction terms are positive, the size and statistical significance of the effects does not rise sharply over time. Moreover, the hypothesis that the coefficients on the interaction terms are equal in 2010 and 2014 cannot be rejected at any reasonable level of statistical significance.

The conflicting results for the two education groups are not entirely surprising because firms should be less inclined to shift higher paid workers to part-time work to avoid the mandate. It is easier to force higher income workers to pay for the coverage and still satisfy the ACA requirement that it be "affordable" to the worker (i.e. less than 9.5\% of earnings).

One potential shortcoming of the above regression approach is that it assumes that the determinants of IPT are identical across industry and occupation. For example, our regression model in (1) assumes that the effect of economic conditions on IPT employment is the same across all industries. If this assumption is violated, it could lead to a spurious relationship between the fraction affected by the ACA and the estimated change in the probability of IPT employment. With a weakening of economic conditions, a regression model that imposes homogeneous business cycle effects across industries would systemically under-predict IPT employment where it is most counter-cyclical. If the fraction affected by the ACA is correlated with the cyclicality of IPT across industries, this could lead to a spurious relationship between the growth in IPT and the fraction affected, which could be magnified (or dampened) if there are changes in the industrial composition of the work force over time.

To minimize the possibility of the aforementioned spurious estimate of the effect of the ACA mandate, we allow the effect of all the control variables to differ by three-digit industry (or occupation) by estimating a separate regression model for each industry (occupation) by education level. These regressions are estimated separately by education group. The models include the same controls as our earlier regressions for economic conditions and worker characteristics, as well as dummy variables for years 2010-2014. The estimated coefficients on the dummy variables indicate the "year effects" for each industry. The estimated year effects are not biased by heterogeneity in the relationship between IPT and economic conditions or, for that matter, any of the other control variables in the model. 
After estimating the 2010-2014 year effects for each industry (or occupation), we use a second stage regression to determine whether the year effects are greater for the industries where the proportion of workers affected by the ACA is largest. That is, we estimate a separate regression of year effects across each industry (or occupation)

(2) $\hat{\theta}_{j t}=a_{t}+b_{t} *$ affect $_{i}+u_{j t}, \quad \mathrm{t}=2010, \ldots 2014$

where $\hat{\theta}_{j t}$ is the estimated year effect for industry (occupation) $\mathrm{j}$ for year $\mathrm{t}$; and affect $\mathrm{j}$ is the estimated proportion of workers affected in industry (occupation) j. The regression model is estimated with weighted least squares with the weights being the sample size used to calculate the proportion affected from the March 2003-2007 Current Population Survey. The standard errors used to calculate the t-statistics are bootstrapped (200 replications) to account for the estimation of the fraction affected. ${ }^{16}$

Table 4 presents the regression results for industry-specific year. The estimated intercepts for the models imply that the probability of IPT employment is slightly higher in 2010-2014 than in the base period for industries where the proportion affected is zero.

For workers without a college degree, the coefficient on the proportion affected is positive in all five regressions estimated, and the size and statistical significance of the effect grows sharply over time. The null hypothesis that the coefficients are equal in 2010 and 2014 is rejected at the .10 level of significance. This lends fairly compelling evidence that the increased probability of IPT employment over the 2010 to 2014 time period was greatest in the industries with the largest fraction of workers affected by the ACA mandate.

For workers with a college degree, the relationship between the changing probability of IPT employment and the fraction of workers affected is much weaker. The coefficient on the fraction affected is positive, but statistically significant (at the .05 level) in only 2014. The pvalue for the null hypothesis that the coefficient on fraction affected is equal in 2010 and 2014 is

\footnotetext{
${ }^{16}$ In the first stage of the bootstrap, we randomly draw with replacement, from within each industry (or occupation) from the March CPS to estimate the fraction affected. In the second stage, we randomly draw (with replacement) entire clusters of industry (or occupation) from the monthly CPS data. The first stage generates variation in the fraction affected by industry (or occupation). The second stage corrects for potential clustering of residuals by industry (occupation).
} 
.06, but the change in the coefficient between 2010 and 2014 is not as smooth as that observed for the less educated group.

In table 5, we report results for the same exercise as in table 4 but this time estimate the fraction affected according to a worker's occupation. While the findings reveal very similar results for the low education group as those in table 4, they point to an even stronger relationship between the growth in IPT employment and the fraction affected over the 2010-2014 time period.

For workers with a college degree, there is stronger evidence that the growth in IPT is associated with the fraction affected by the mandate when using the occupation-specific measure. Unlike the earlier results in table 4, the coefficient on fraction affected rises sharply over time and is significantly different (.01 level) in 2010 and 2014.

One possible explanation for the stronger effects when the occupation-specific rather than the industry-specific measure of fraction affected is employed is that occupation-specific measures of the fraction affected could be a more accurate predictor of whether a particular worker is likely to be affected. For example, the fact that a worker is a server might be a better predictor of whether a worker would be affected by the ACA than the fact that they are employed in the restaurant industry - particularly when education is already controlled for. If occupation specific measures are more accurate, there will be less attenuation bias in the coefficient estimate, and estimated effects would be larger.

One limitation of this two-step analysis is its assumption that, for a given education group, the effect of the mandate on part-time employment varies only with the percentage of workers affected. In fact, we expect that the effect would vary across workers depending on the nature of the job. The ACA limits the employee contribution for health insurance to $9.5 \%$ of household income for those receiving a subsidy. Thus, if the wage rate of a worker is higher, the firm is more able to pass on the cost of health insurance to worker. Consequently, workers in high-wage industries would likely be less threatened with a switch to part-time employment as a result of the mandate.

To test this prediction, we merge the mean real hourly wage (in 2014 dollars) by 3-digit occupation and education group from the 2010-2014 Outgoing Rotation Groups of the CPS, and re-estimate the regressions of the occupation specific change in the probability of IPT employment on the fraction affected by adding the hourly wage and an interaction between the 
hourly wage and the fraction affected. The expectation is that the mandate would be less likely to increase IPT employment in occupations with high hourly wages. Thus, we expect a negative coefficient on the interaction term between the wage rate and fraction affected.

The results are presented in table 6. To facilitate the interpretation of coefficients, the fraction affected and the hourly wage are measured as deviations from sample means. For simplicity, we first focus on the results for workers without a college degree. Since the control variables are measured as deviations from means, the estimates of the intercept reveal the change in the probability of IPT for the occupation with the average wage and average fraction affected. The fact that the intercept is positive and statistically significant in every year since 2010 and is rising over time implies that the probability of IPT has been rising gradually over time. The rising coefficient on the fraction affected variable over time implies that the probability of IPT rose most for workers in occupations where a large fraction would be affected by the mandate.

The negative coefficient on the interaction between fraction affected and hourly wage indicates that when holding the fraction affected by the mandate constant, the increase in the probability of IPT employment relative to the base period is smaller in high-wage occupations. Moreover, the size of the relevant coefficient and its statistical significance grows over time. This implies that the mandate's effect is not uniform across affected workers and that, conditional on the mandate applying to a fixed fraction of workers in an occupation, the probability of IPT employment grew most quickly in the occupations with low hourly wages. As an illustration of the magnitude of this effect, consider a low-wage and a high-wage occupation with average wages, respectively, $\$ 5$ below and \$5 above the average wage, both groups having the average fraction of workers affected. In the high-wage occupation, the model for the low education group implies that the probability of IPT employment is 0.0025 higher in 2014 than in the base period. In the low-wage occupation, the probability of IPT is 0.0115 higher in 2014 than in the base period. While these differences between high and low wage workers may seem small in magnitude, they are quite large relative to the average probability of IPT (around .03 for the less educated workers in 2014).

Inspection of the results for workers with at least a college degree reveals a very similar pattern to that observed above. For example, the pattern of coefficients implies that the rate of growth in the probability of IPT since 2010 is greatest in low-wage occupations and in occupations with a higher fraction of workers affected. 
To provide a sense of the quantitative importance of our results, we use the model in table 6 to compute the implied change in IPT employment due to the ACA. In particular, we compute the predicted change in the probability of IPT employment that would occur if the occupation-specific fraction of workers affected by the ACA is switched from the observed value to zero. We then multiply this occupation-specific increase in the probability of IPT employment by the level of employment in that occupation. ${ }^{17}$

Table 7 presents our estimated changes in IPT employment due to the ACA using the above methods. The estimated increase in IPT relative to the base-period of 1994-2009 is approximately 1,057,000 and 266,000 for the low and high education subsamples, respectively. This totals 1.3 million additional workers in IPT employment. Moreover, the estimates reveal that the IPT effects have grown sharply over time, particularly for workers without a college degree.

Robustness of Results.

While the above empirical results are largely consistent with the theory that ACA causes IPT employment to rise, it is important to test the robustness of the results to alternative specifications. First, we examine whether the reference period substantially alters the results. To do this, we also consider reference periods of 1994-2007 and 1994-2011 (instead of 19942009). We repeat the same two-step methodology as above and examine the final prediction regarding the growth in IPT employment due to the ACA. The results are included in Figure 4 and appendix table A2. A comparison of results across all three reference periods reveals that the results are robust. Across all 3 reference periods, the range of estimates for the 2014 increase in IPT employment is 951,000 to 1,069,000 for those without a college degree, and 200,000 to 266,000 for those with a college degree. For all three reference periods, the importance of the fraction affected rose in the few years prior to 2014. One potential concern is that with the shortest reference period (1994-2007), there appears to be an increase in IPT employment associated with the fraction affected by the ACA as early as 2008; yet, the effect is

\footnotetext{
17 An alternative approach is to use the 2014 level of employment rather than the actual level of employment in a given year. This method removes any effects of shifts in the occupation distribution of employment on IPT. This approach changes the results very little.
} 
essentially flat from 2008 to 2010 and then begins to rise monotonically after 2010. Given this result, differencing out any effect that existed already in 2010 could provide a more conservative estimate of the effect of the ACA. This exercise results in an estimated increase in IPT employment of 875,000 to 900,000 for workers without a college degree and 139,000 to 162,000 for workers with a college degree.

Another possible explanation of our results is that the growth in IPT employment is the result of structural change in the economy caused by technological change. Autor and Dorn (2013) discuss the growth of low-skill service jobs that was partly driven by technological change that displaced workers in occupations that performed routine tasks. Canon et al. (2014) provide evidence that the growth of IPT employment has become more common since 2010, and that the growth has been faster in non-routine (typically, service) than routine (typically, goodsproducing) jobs.

If our occupation-specific estimate of the fraction affected by the ACA varies systematically with the impact of technological change, our estimated effect of the ACA could be biased and capturing what is actually the effect of technological change. To test for this, we merge Autor and Dorn's occupation specific measure of “routine task intensity” (RTI) to our data and repeat the second stage regressions reported in table 6. If technological change explains the patterns observed in our analysis, controlling for RTI should reduce or eliminate the explanatory power of the fraction affected by the ACA for the growth in IPT employment. The results (provided in appendix table A3) imply that IPT employment rose at a slower rate in RTI jobs since 2010. However, there is no statistically significant effect of RTI on the IPT employment until 2013. More importantly, the addition of RTI to our model alters the estimated effect of the fraction affected by the ACA only slightly, and if anything, slightly strengthens the estimated effect of the ACA.

Who are the affected workers?

Table 8 presents the increase in probability of IPT employment due to the ACA for different subgroups of the population. The models from table 6 are used to calculate the change in the probability of IPT relative to the base-period of 1994-2009 that would result if the fraction affected in each 3-digit occupation changed from actual values to zero. The occupation-specific 
change in the probability of IPT is merged back to the individual-level CPS data, and the mean change in the probability of IPT is calculated for each subgroup of workers.

Several patterns emerge in the table. First, the increase in the probability of IPT employment is larger among women, younger workers, and African-Americans for both education groups. Second, substantial variation exists in the change in the probability of IPT employment across major occupations and among workers without a college degree. For example, service occupations (excluding protective and household services) had nearly twice (.024) the average increase in the probability of IPT employment (0.013). At the other extreme, professional specialty occupations had no change in the probability of IPT employment. There is significant variation in the effect of the ACA across detailed occupations within these broad categories as well. Restricting attention to occupations with at least 100,000 employees in 2014, we estimate that the largest increase in the probability of IPT employment caused by the ACA is for cashiers (.045) and kitchen and food preparation workers (.044). Third, the retail industry had the largest rise in the probability of IPT employment for both education groups. In fact, all of the 16 3-digit industries with the largest increase in the probability of IPT employment are in the retail industry for workers without a college degree.

\section{Summary and Conclusions.}

Starting in 2015, the Affordable Care Act will impose penalties on large employers that do not provide affordable health insurance to their full-time employees. This study investigates whether employers have shifted from full-time to part-time workers to avoid these penalties. Our estimation of models of part-time employment that control for changing economic conditions, worker characteristics, and occupational and industrial composition suggest that IPT employment between 2010 and 2014 was higher than predicted based on a reference period of 1994-2009. More importantly, we find that the increase in IPT employment over the past few years was greatest in the industries and occupations that employed the largest percentage of workers who would be affected by the mandate: those employed at a large firm without health insurance coverage. This result persists even in models where we allow the effects of the economy and worker characteristics to vary by occupation or industry. We believe this provides strong evidence that the ACA penalties have caused a shift to IPT employment. 
The empirical analysis indicates that the ACA employer mandate has had a quantitatively important impact on IPT employment. As much as $1.2 \%$ to $1.4 \%$ of workers without a college degree are involuntary employed part-time as a result of the ACA employer mandate. In our sample this translates into approximately one-million additional involuntary part-time workers, though the estimate varies slightly depending on the reference period chosen. The mandate's effect was not uniform across affected workers. The probability of IPT employment grew most for affected workers in the occupations with low hourly wages.

Overall, we believe this study presents fairly strong evidence that the rise in involuntary part-time work since 2010 has been greatest in the industries and occupations where the ACA employer mandate is most likely to be binding. While it is conceivable that there are other structural changes at work that explain differential growth in IPT employment across occupations or industries, we are unaware of any such structural change that would have grown in importance since 2010 in the industries and occupations where the ACA is most likely to be binding. We consider this to be a challenge for future research in this area. 


\section{References.}

ADP Research Institute, "The Affordable Care Act and Economics of the Part-Time Workforce: Measuring the Impact of the Affordable Care Act,” 2015. http://www.adp.com/tools-andresources/adp-research-institute/research-and-trends/research-itemdetail.aspx?id=752D5867-509A-4021-841D-570F5AAE5566

Autor, David H., and Dorn, David. ““"The Growth of Low Skill Service Jobs and the Polarization of the U.S. Labor Market.” American Economic Review 103 (December 2013): 1553 1597.

Barrett, Garry F., and Doiron, Denise J. "Working Part Time: By Choice or by Constraint." Canadian Journal of Economics 34 (November 2001): 1042-1065.

Bollinger, Christopher R., and Hirsch, Barry T. "Match Bias from Earnings Imputation in the Current Population Survey: The Case of Imperfect Matching." Journal of Labor Economics 24 (July 2006): 483-519.

Cajner, Tomaz; Mawhirter, Dennis; Nekarda, Christopher; and Ratner, David. "Why is Involuntary Part-Time Work Elevated?” FEDS Notes, April 14, 2014.

Canon, Maria E., Kudlyak, Marianna; Luo, Guannan; and Reed, Marisa. "Flows To and From Working Part Time for Economic Reasons and the Labor Market Aggregates During and After the 2007-09 Recession." Economic Quarterly 2Q (2014): 87-111.

Congressional Budget Office. “The Budget and Economic Outlook: 2014 to 2024.” February 2014.

Dillender, Marcus; Heinrich, Carolyn J.; Houseman, Susan N. "The Potential Effects of Federal Health Insurance Reforms on Employment Arrangements and Compensation,” Upjohn Institute Working Paper 15-228, April 2015.

Ehrenberg, Ronald G.; Rosenberg, Pamela; and Li, Jeanne. "Part-time Employment in the United States.” In R. A. Hart (ed.), Employment, Unemployment and Labor Utilization. (Boston, MA: Unwin Hyman, Inc., 1988), pp. 256-281.

Euwals, Rob, and Hogerbrugge, Maurice. "Explaining the Growth of Part-Time Employment: Factors of Supply and Demand.” Labour 20 (September 2006): 533-557.

Garrett, Bowen, and Kaestner, Robert. "Little Evidence of the ACA Increasing Part-Time Work So Far.” Urban Institute In-Brief, September 2014. 
. "Recent Evidence on the ACA and Employment: Has the ACA Been a Job Killer?” Urban Institute Working Paper, August 2015.

Mathur, Aparna; Slavova, Sita Nataraj; and Strain, Michael R. "Has the Affordable Care Act Increased Part-Time Employment?” Applied Economics Letters, forthcoming.

Mulligan, Casey. "The Affordable Care Act and the New Economics of Part-Time Work. Mercatus Working paper, Mercatus Center at George Mason University, Arlington VA. October 2014.

U.S. Census Bureau. "The Relationship Between the 1990 Census and Census 2000 Industry and Occupation Classification Systems,” Technical Working Paper Number 65, October 2003.

Valletta, Robert G, and Bengali L. “What's Behind the Increase in Part-Time Work?” Federal Reserve Bank of San Francisco Economic Letter 2013-24, August 26, 2013.

Valletta, Rob, and Van Der List, Catherine. “Involuntary Part-Time Work: Here to Stay?” Federal Reserve Bank of San Francisco Economic Letter 2015-19. June 8, 2015.

Welch, Finis. "Wages and Participation." Journal of Labor Economics (1997): S77-S103.

Yellen, Janet. "Labor Market Dynamics and Monetary Policy.” Speech at the FRB Kansas City Economic Symposium, Jackson Hole, Wyoming (August 22, 2014). http:// www.federalreserve.gov/ newsevents/ speech/yellen20140822a.htm 
Table 1. Key Affordable Care Dates

Legislation Dates:

Passed Senate

December 24, 2009

Passed House

March 21, 2010

Signed into Law by President

March 23, 2010

Upheld by Supreme Court

June 28, 2012

Original Dates in Legislation:

Start of Health Insurance Exchange

October 1, 2013

Employee Fines Start for No Coverage

January 1, 2014

Subsidies Made Available

January 1, 2014

Revised Dates:

Delay of Employer Fines Until 2015

Delay of Employer Fines Until 2016 for 50-99 Employee Firms

Coverage Requirement for 100+ Employee Firms changed to 70

July 2, 2013

February 10, 2014

percent for 2015 and 95 percent by 2016

February 10, 2014

Note: The legislation dates are from U.S. Senate, Committee on Finance (http://www.finance.senate.gov/issue/?id=32be19bd-491e-4192-812f-f65215c1ba65). The implementation dates for Affordable Care Act are from Kaiser Family Foundation (http://kff.org/interactive/implementation-timeline/). 
Table 2.

Regression Models of Voluntary and Involuntary Part-Time by Education Group.

\begin{tabular}{|c|c|c|c|c|}
\hline & \multicolumn{2}{|c|}{ Education $<16$} & \multicolumn{2}{|c|}{ Education $>=16$} \\
\hline & $\begin{array}{l}\text { Voluntary } \\
\text { Part-Time }\end{array}$ & $\begin{array}{l}\text { Involuntary } \\
\text { Part-Time }\end{array}$ & $\begin{array}{l}\text { Voluntary } \\
\text { Part-Time }\end{array}$ & $\begin{array}{l}\text { Involuntary } \\
\text { Part-Time }\end{array}$ \\
\hline 2010 & $\begin{array}{l}-0.005 \\
(-4.97)\end{array}$ & $\begin{array}{l}0.004 \\
(4.63)\end{array}$ & $\begin{array}{l}-0.007 \\
(-5.52)\end{array}$ & $\begin{array}{l}0.002 \\
(3.35)\end{array}$ \\
\hline 2011 & $\begin{array}{l}-0.004 \\
(-2.68)\end{array}$ & $\begin{array}{l}0.006 \\
(7.06)\end{array}$ & $\begin{array}{l}-0.009 \\
(-7.22)\end{array}$ & $\begin{array}{l}0.003 \\
(4.67)\end{array}$ \\
\hline 2012 & $\begin{array}{l}-0.003 \\
(-2.00)\end{array}$ & $\begin{array}{l}0.007 \\
(9.10)\end{array}$ & $\begin{array}{l}-0.012 \\
(-8.14)\end{array}$ & $\begin{array}{l}0.003 \\
(6.41)\end{array}$ \\
\hline 2013 & $\begin{array}{l}-0.004 \\
(-3.68)\end{array}$ & $\begin{array}{c}0.010 \\
(11.35)\end{array}$ & $\begin{array}{l}-0.014 \\
(-10.87)\end{array}$ & $\begin{array}{l}0.004 \\
(8.05)\end{array}$ \\
\hline 2014 & $\begin{array}{l}-0.002 \\
(-1.49)\end{array}$ & $\begin{array}{c}0.011 \\
(11.57)\end{array}$ & $\begin{array}{l}-0.013 \\
(-10.25)\end{array}$ & $\begin{array}{l}0.004 \\
(9.77)\end{array}$ \\
\hline Unemployment Rate & $\begin{array}{l}0.004 \\
(0.15)\end{array}$ & $\begin{array}{c}0.427 \\
(20.31)\end{array}$ & $\begin{array}{l}-0.060 \\
(-2.10)\end{array}$ & $\begin{array}{c}0.155 \\
(12.38)\end{array}$ \\
\hline Coincident Index/100 & $\begin{array}{l}-0.022 \\
(-7.45)\end{array}$ & $\begin{array}{l}-0.005 \\
(-3.39)\end{array}$ & $\begin{array}{l}-0.008 \\
(-1.82)\end{array}$ & $\begin{array}{l}-0.004 \\
(-2.64)\end{array}$ \\
\hline Leading Indicator/100 & $\begin{array}{l}0.053 \\
(2.95)\end{array}$ & $\begin{array}{l}0.015 \\
(1.25)\end{array}$ & $\begin{array}{l}0.057 \\
(2.55)\end{array}$ & $\begin{array}{l}0.016 \\
(1.98)\end{array}$ \\
\hline Sample Size & $8,773,043$ & $8,773,043$ & $3,781,186$ & $3,781,186$ \\
\hline $\begin{array}{l}R^{2} \\
p \text {-value for } 2010=2014 *\end{array}$ & $\begin{array}{c}0.120 \\
0.0442\end{array}$ & $\begin{array}{l}0.024 \\
0.000\end{array}$ & $\begin{array}{l}0.083 \\
0.000\end{array}$ & $\begin{array}{l}0.014 \\
0.000\end{array}$ \\
\hline
\end{tabular}

Note: The coefficients are for the education group's part-time status ( $<30$ hours per week) and parttime involuntary status using January 1994 to December 2014 Current Population Survey data. The models include controls for major industry (22 categories); major occupation (13 categories); month, state (51 categories); age (5 categories); race (3 categories); female, marital status (3 categories); female interacted with marital status (2 categories); education (3 categories); and female interacted with number of children aged 0 to 5 and aged 6 to 17 (4 categories). Standard errors are estimated with clustering of residuals by state.

*P-value is for test of null hypothesis that coefficient on 2010 and 2014 year dummies are equal. 
Table 3. Determinants of Involuntary Part-Time Employment.

\begin{tabular}{|c|c|c|c|c|}
\hline \multirow[b]{2}{*}{ Year dummies: } & \multicolumn{2}{|c|}{$\begin{array}{c}\text { Less than } 16 \text { years of } \\
\text { education }\end{array}$} & \multicolumn{2}{|c|}{$\begin{array}{c}16 \text { or more years of } \\
\text { education }\end{array}$} \\
\hline & & & & \\
\hline \multirow[t]{2}{*}{2010} & -0.005 & -0.005 & -0.001 & -0.001 \\
\hline & $(-1.48)$ & $(-1.20)$ & $(-0.71)$ & $(-0.92)$ \\
\hline \multirow[t]{2}{*}{2011} & -0.006 & -0.006 & -0.004 & 0.000 \\
\hline & $(-1.63)$ & $(-1.38)$ & $(-2.08)$ & $(0.21)$ \\
\hline \multirow[t]{2}{*}{2012} & -0.010 & -0.007 & -0.005 & 0.002 \\
\hline & $(-2.28)$ & $(-2.21)$ & $(-2.30)$ & (1.09) \\
\hline \multirow[t]{2}{*}{2013} & -0.014 & -0.008 & -0.001 & 0.001 \\
\hline & $(-2.82)$ & $(-2.68)$ & $(-0.41)$ & $(0.37)$ \\
\hline \multirow[t]{2}{*}{2014} & -0.015 & -0.010 & -0.004 & -0.002 \\
\hline & $(-3.10)$ & $(-2.86)$ & $(-1.52)$ & $(-0.64)$ \\
\hline \multirow[t]{2}{*}{ Fraction Affected } & 0.065 & 0.028 & 0.011 & 0.079 \\
\hline & $(0.74)$ & $(0.34)$ & $(0.25)$ & $(1.75)$ \\
\hline \multicolumn{5}{|l|}{ Year dummies interacted with fraction affected } \\
\hline \multirow[t]{2}{*}{$2010 *$ Affected } & 0.057 & 0.062 & 0.014 & 0.017 \\
\hline & $(2.38)$ & $(2.09)$ & $(0.76)$ & $(1.48)$ \\
\hline \multirow[t]{2}{*}{$2011 *$ Affected } & 0.081 & 0.080 & 0.044 & 0.011 \\
\hline & $(3.47)$ & $(2.67)$ & $(2.41)$ & $(0.69)$ \\
\hline \multirow[t]{2}{*}{$2012 *$ Affected } & 0.110 & 0.094 & 0.059 & 0.002 \\
\hline & $(3.96)$ & $(4.09)$ & $(2.75)$ & $(0.15)$ \\
\hline \multirow[t]{2}{*}{$2013 *$ Affected } & 0.148 & 0.113 & 0.020 & 0.011 \\
\hline & $(4.38)$ & $(4.65)$ & $(0.59)$ & $(0.66)$ \\
\hline \multirow[t]{2}{*}{$2014 *$ Affected } & 0.164 & 0.132 & 0.045 & 0.038 \\
\hline & $(4.74)$ & $(4.11)$ & $(1.80)$ & (1.65) \\
\hline \multirow{2}{*}{$\begin{array}{l}\text { Fraction affected estimated by } \\
\text { p-value for equal coefficients on } 2010 \text { and } 2014 \\
\text { interaction terms* }\end{array}$} & Occupation & Industry & Occupation & Industry \\
\hline & 0.002 & 0.000 & 0.194 & 0.324 \\
\hline $\mathrm{R}^{2}$ & 0.030 & 0.027 & 0.008 & 0.008 \\
\hline Sample Size & $8,773,043$ & $8,773,043$ & $3,781,186$ & $3,781,186$ \\
\hline
\end{tabular}

Note: The linear probability models also include all of the controls listed Table 2 as well as an estimate of the percentage of workers affected by the ACA mandate in a worker's industry or occupation, and its interaction with the unemployment rate, coincident index, and leading indicator. Fraction affected is estimated as the proportion of the relevant education group's 3 digit occupation or industry that worked 30 or more hours per week at a firm with 100 or more employees without employer provided health insurance in the March 2003-2007 Current Population Survey. The standard errors are bootstrapped 200 times to adjust for estimation of the proportion affected, and clustering of residuals by industry or occupation.

*P-value is for test of null hypothesis that coefficient on interaction term between year dummy and fraction affected is equal for 2010 and 2014. 
Table 4. Relationship between Industry Specific Measure of Proportion Affected by ACA and Growth in Involuntary Part-Time Employment.

\begin{tabular}{|c|c|c|c|c|c|}
\hline \multirow[b]{2}{*}{ Variable } & \multicolumn{5}{|c|}{ Part-Time Involuntary } \\
\hline & 2010 & 2011 & 2012 & 2013 & 2014 \\
\hline & \multicolumn{5}{|c|}{ Less than 16 years of Education } \\
\hline \multirow[t]{2}{*}{ Affect } & 0.024 & 0.024 & 0.043 & 0.066 & 0.079 \\
\hline & $(1.61)$ & $(1.86)$ & $(3.47)$ & $(3.13)$ & $(3.29)$ \\
\hline \multirow[t]{2}{*}{ Constant } & 0.003 & 0.005 & 0.006 & 0.009 & 0.010 \\
\hline & $(5.85)$ & $(7.68)$ & $(8.25)$ & $(8.44)$ & $(7.56)$ \\
\hline $\begin{array}{l}\text { p-value for equal coefficient on Affect } \\
\text { in } 2010 \text { and } 2014\end{array}$ & \multicolumn{5}{|c|}{0.053} \\
\hline Observations & 233 & 233 & 233 & 233 & 233 \\
\hline \multirow[t]{2}{*}{ R-squared } & 0.055 & 0.043 & 0.117 & 0.110 & 0.187 \\
\hline & \multicolumn{5}{|c|}{16 or more years of education } \\
\hline \multirow[t]{2}{*}{ Affect } & 0.002 & 0.030 & 0.002 & 0.027 & 0.074 \\
\hline & $(0.10)$ & $(1.62)$ & $(0.07)$ & $(1.36)$ & $(2.26)$ \\
\hline \multirow[t]{2}{*}{ Constant } & 0.001 & 0.003 & 0.004 & 0.004 & 0.004 \\
\hline & $(2.36)$ & $(4.28)$ & (5.99) & (6.74) & (5.68) \\
\hline $\begin{array}{l}\text { p-value for equal coefficient on Affect } \\
\text { in } 2010 \text { and } 2014\end{array}$ & & & 0.062 & & \\
\hline Observations & 208 & 208 & 208 & 208 & 208 \\
\hline $\mathrm{R}^{2}$ & 0.000 & 0.017 & 0.000 & 0.014 & 0.069 \\
\hline
\end{tabular}

Note: For each 3-digit industry, a linear probability model of part-time employment is estimated with controls for personal characteristics of workers and economic conditions. The sample period is 1994 through 2014. Year dummies are included for 2010 through 2014. The coefficients on the year dummies represent the change in the probability of part-time employment relative to the base period (1994-2009). For each year between 2010 and 2014, this estimate of the industry specific change in the probability of part-time employment is regressed on our estimate of the percentage of that industry's workers that would be affected by the ACA employer mandate. The regressions are weighted by the industry-specific sample size used to estimate the percent of workers affected. Tstatistics are based on bootstrapped standard errors (200 replications) correcting for the estimation of percent affected and clustering by industry. Additional details are included in the text. 
Table 5. Relationship between Occupation Specific Measure of Proportion Affected by ACA and Growth in Involuntary Part-Time Employment.

\begin{tabular}{|c|c|c|c|c|c|}
\hline \multirow[b]{2}{*}{ Variable } & \multicolumn{5}{|c|}{ Part-Time Involuntary } \\
\hline & 2010 & 2011 & 2012 & 2013 & 2014 \\
\hline & \multicolumn{5}{|c|}{ Less than 16 years of Education } \\
\hline \multirow[t]{2}{*}{ Affect } & 0.025 & 0.046 & 0.059 & 0.100 & 0.129 \\
\hline & $(2.24)$ & $(4.40)$ & $(5.05)$ & $(5.92)$ & (5.79) \\
\hline Constant & 0.003 & 0.005 & 0.006 & 0.007 & 0.009 \\
\hline & $(6.59)$ & $(8.11)$ & $(8.42)$ & $(12.20)$ & $(11.68)$ \\
\hline $\begin{array}{l}\text { p-value for equal coefticient on Affect } \\
\text { in } 2010 \text { and 2014* }\end{array}$ & & & 0.000 & & \\
\hline Observations & 403 & 403 & 403 & 403 & 403 \\
\hline R-squared & 0.032 & 0.081 & 0.116 & 0.262 & 0.336 \\
\hline
\end{tabular}

16 or more years of education

\begin{tabular}{lccccc} 
Affect & 0.028 & 0.066 & 0.068 & 0.083 & 0.114 \\
& $(1.78)$ & $(3.11)$ & $(3.42)$ & $(3.95)$ & $(4.93)$ \\
Constant & 0.001 & 0.003 & 0.004 & 0.005 & 0.005 \\
& $(2.48)$ & $(4.77)$ & $(5.60)$ & $(5.89)$ & $(6.33)$ \\
p-value for equal coefficient on Affect & & & & & \\
in 2010 and 2014* & & & 0.002 & & \\
Observations & 297 & 297 & 297 & 297 & 297 \\
$\mathrm{R}^{2}$ & 0.010 & 0.042 & 0.046 & 0.079 & 0.111 \\
\hline
\end{tabular}

Note: For each 3-digit occupation, a linear probability model of part-time employment is estimated with controls for personal characteristics of workers and economic conditions. The sample period is 1994 through 2014. Year dummies are included for 2010 through 2014. The coefficients on the year dummies represent the change in the probability of part-time employment relative to the base period (1994-2009). For each year between 2010 and 2014, this estimate of the occupation-specific change in the probability of part-time employment is regressed on our estimate of the percentage of that occupation's workers who would be affected by the ACA employer mandate. The regressions are weighted by the occupation-specific sample size used to estimate the percent of workers affected. Tstatistics are based on bootstrapped standard errors (200 replications) correcting for the estimation of percent affected and clustering by occupation Additional details are included in the text. 
Table 6. The Effect of Proportion Affected and Hourly Wage on Growth in Occupation-Specific Increase in Involuntary Part-Time Employment.

\begin{tabular}{|c|c|c|c|c|c|}
\hline & 2010 & 2011 & 2012 & 2013 & 2014 \\
\hline & \multicolumn{5}{|c|}{ Education $<16$} \\
\hline \multirow[t]{2}{*}{ Affect } & 0.008 & 0.019 & 0.013 & 0.038 & 0.049 \\
\hline & $(0.65)$ & $(1.20)$ & $(0.97)$ & $(2.57)$ & $(2.80)$ \\
\hline \multirow[t]{2}{*}{ Wage/10 } & -0.002 & -0.004 & -0.005 & -0.008 & -0.009 \\
\hline & $(-2.30)$ & $(-2.58)$ & $(-3.59)$ & $(-5.84)$ & $(-5.02)$ \\
\hline \multirow[t]{2}{*}{ Affect* Wage/10 } & -0.016 & -0.023 & -0.056 & -0.077 & -0.113 \\
\hline & $(-0.90)$ & $(-1.03)$ & $(-2.71)$ & $(-3.33)$ & $(-3.90)$ \\
\hline \multirow[t]{2}{*}{ Constant } & 0.003 & 0.004 & 0.005 & 0.006 & 0.007 \\
\hline & $(5.30)$ & $(6.05)$ & (6.67) & $(9.73)$ & $(9.22)$ \\
\hline Observations & 403 & 403 & 403 & 403 & 403 \\
\hline \multirow[t]{2}{*}{ R-squared } & 0.0502 & 0.116 & 0.192 & 0.373 & 0.476 \\
\hline & \multicolumn{5}{|c|}{ Education $>=16$} \\
\hline \multirow[t]{2}{*}{ Affect } & 0.028 & 0.045 & 0.050 & 0.046 & 0.069 \\
\hline & $(1.63)$ & $(2.08)$ & $(2.45)$ & $(2.52)$ & $(3.24)$ \\
\hline \multirow[t]{2}{*}{ Wage/10 } & 0.000 & -0.002 & -0.001 & -0.004 & -0.005 \\
\hline & $(0.01)$ & $(-2.43)$ & $(-1.15)$ & $(-4.29)$ & $(-4.78)$ \\
\hline \multirow[t]{2}{*}{ Affect* Wage/10 } & 0.007 & -0.018 & -0.011 & -0.039 & -0.053 \\
\hline & $(0.48)$ & $(-0.81)$ & $(-0.50)$ & $(-2.07)$ & $(-2.16)$ \\
\hline \multirow[t]{2}{*}{ Constant } & 0.001 & 0.004 & 0.002 & 0.006 & 0.006 \\
\hline & $(2.24)$ & $(4.37)$ & $(2.21)$ & $(5.55)$ & $(6.67)$ \\
\hline Observations & 297 & 297 & 297 & 297 & 297 \\
\hline $\mathrm{R}^{2}$ & 0.011 & 0.061 & 0.0834 & 0.152 & 0.195 \\
\hline
\end{tabular}

Note: The regressions are weighted by the March 2003-2007 Current Population Survey sample size for estimating proportion affected. The variables of affect and wage are measured as deviations from means. The regressions are weighted by the occupation-specific sample size used to estimate the percent of workers affected. T-statistics are based on bootstrapped standard errors (200 replications) correcting for the estimate of fraction affected. Additional details are included in the text. 
Table 7. Changes in Involuntary Part-Time Employment Relative to 1994-2009 Sample Period due to ACA. ${ }^{a}$

$\begin{array}{lcccccc} & 2010 & 2011 & 2012 & 2013 & 2014 & \begin{array}{c}2010 \text { to } 2014 \\ \text { change }\end{array} \\ & & & & & & \\ \begin{array}{l}\text { Less than 16 years of } \\ \text { education }\end{array} & \begin{array}{l}156.1 \\ (0.2 \%)\end{array} & \begin{array}{c}319.8 \\ (0.4 \%)\end{array} & \begin{array}{c}378.8 \\ (0.5 \%)\end{array} & \begin{array}{c}764.9 \\ (1.0 \%)\end{array} & \begin{array}{c}1,056.5 \\ (1.4 \%)\end{array} & \begin{array}{c}900.4 \\ (1.2 \%)\end{array} \\ \begin{array}{l}\text { 16 or more years of } \\ \text { education }\end{array} & 126.5 & 176.8 & 154.8 & 168.9 & 265.5 & 139.0 \\ & (0.3 \%) & (0.5 \%) & (0.4 \%) & (0.4 \%) & (0.6 \%) & (0.3 \%)\end{array}$

Note: Estimated increase in involuntary part-time employment (IPT) is estimated using models from table 6 to calculate the change in the probability of IPT that would result if the fraction affected in each occupation changed from actual values to zero. The occupation specific change in the probability of IPT in a given year is multiplied by the occupation-specific employment level. All employment estimates are in 1000s. The numbers in parentheses are the increases divided by the level of employment. 
Table 8. Increase in Probability of Involuntary Part-Time Employment by Subgroup

$\begin{array}{ccc} & \text { Education }<16 & \text { Education }>=16 \\ \text { Population } & & \\ \text { Male } & 0.013 & 0.006 \\ \text { Female } & 0.011 & 0.005 \\ & 0.016 & 0.007\end{array}$

Age group

$19-24$

0.020

0.009

25-29

0.015

0.007

30-39

0.012

0.006

40-49

0.011

0.006

50-59

0.011

0.006

60-64

0.012

0.006

Race

White

0.012

0.006

African-American

0.016

0.008

Other

0.016

0.006

Occupation

$\begin{array}{lll}\text { Executive, administrative, and managerial occupations } & 0.002 & 0.003\end{array}$

Professional specialty occupation $\quad 0.001$

0.004

Technicians and related support occupations

0.004

0.006

Sales occupations

0.022

0.009

Administrative support occupations, including clerical

0.014

0.014

Private household occupations

0.023

0.021

Protective service occupations

0.010

0.007

Service occupations, except protective and household

0.024

0.018

Precision production, craft, and repair

0.016

0.006

Machine operators, assemblers, and inspectors

0.004

0.007

Transportation and material moving

0.014

0.011

Handlers, equipment cleaners, and helpers

0.010

0.018

Farming, forestry, and fishing occupations

0.021

0.022 
Table 8. Increase in Probability of Involuntary Part-Time Employment by Subgroup.

Industry

Agriculture, Forestry, and Fisheries

Mining

Construction

Manufacturing Durable Goods

Manufacturing Nondurable Goods

Transportation, Communication, and Other Utilities

Wholesale Trade

Retail Trade

Finance, Insurance, and Real Estate

Business and Repair Services

Personal Services Including Private Households

Entertainment and Recreation Services

Professional and Related Services

Public Administration
Education $<16 \quad$ Education $>=16$

$0.014 \quad 0.005$

$0.003 \quad 0.003$

$0.004 \quad 0.004$

$0.009 \quad 0.003$

$0.013 \quad 0.005$

$0.008 \quad 0.006$

$0.011 \quad 0.005$

$0.025 \quad 0.013$

$0.006 \quad 0.005$

$0.011 \quad 0.004$

$0.016 \quad 0.010$

$0.015 \quad 0.006$

$0.012 \quad 0.006$

$0.005 \quad 0.005$

Note: Estimated increase in involuntary part-time employment (IPT) probability is estimated using models from table 6 to calculate the change in the probability of IPT that would result if the fraction affected in each occupation changed from actual values to zero. The occupation-specific change in the probability of IPT is merged back to the individual-level data, and the mean change in change in the probability of IPT is calculated for each subgroup of workers. 


\section{Figure 1: Part Time Voluntary}
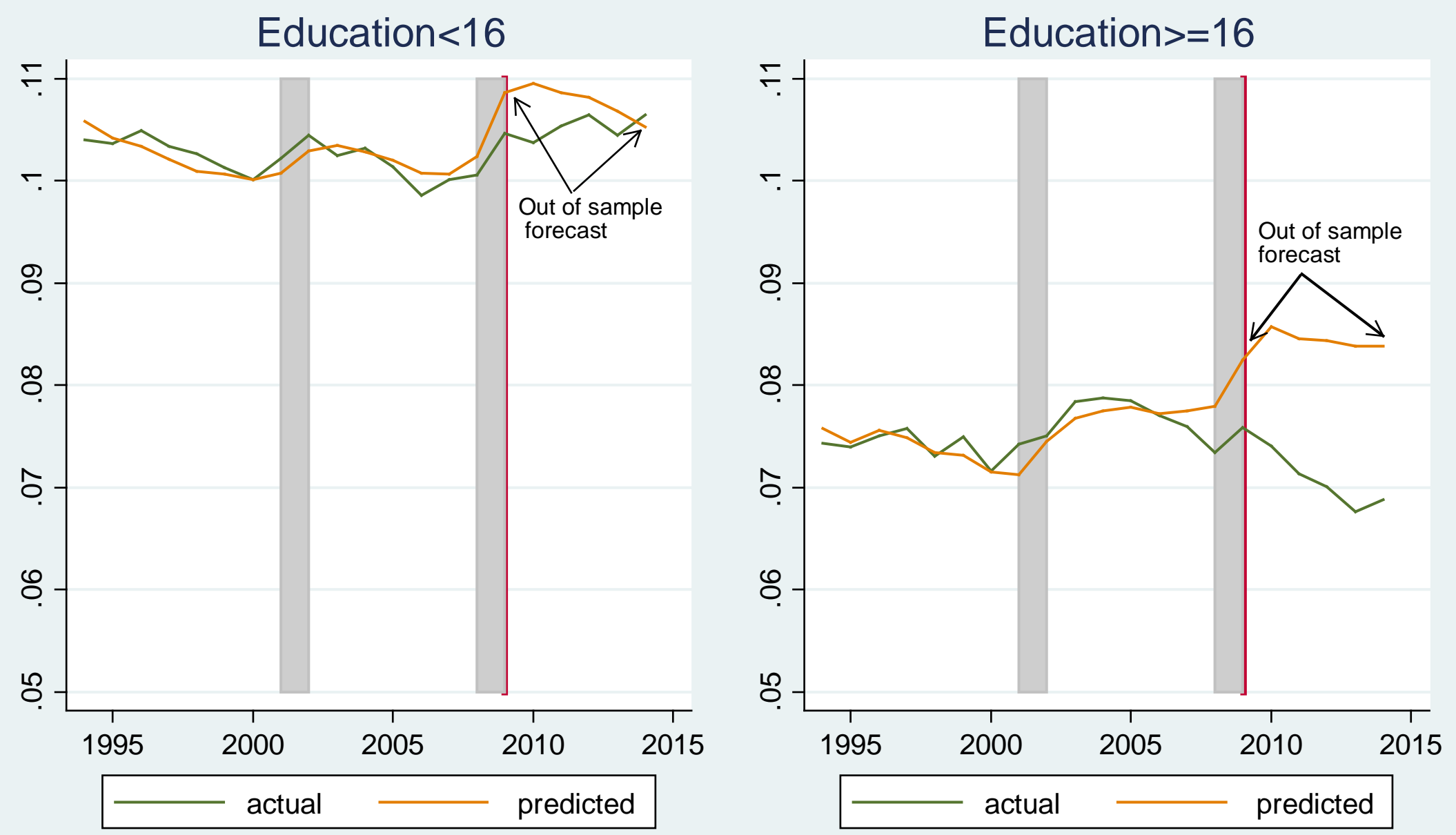

Predictions are based on a linear probability model using data from 1994-2009 controlling for economic conditions, industry,occupation, and personal characteristics of workers. Monthly predictions are converted to annual averages. 


\section{Figure 2: Involuntary Part Time}
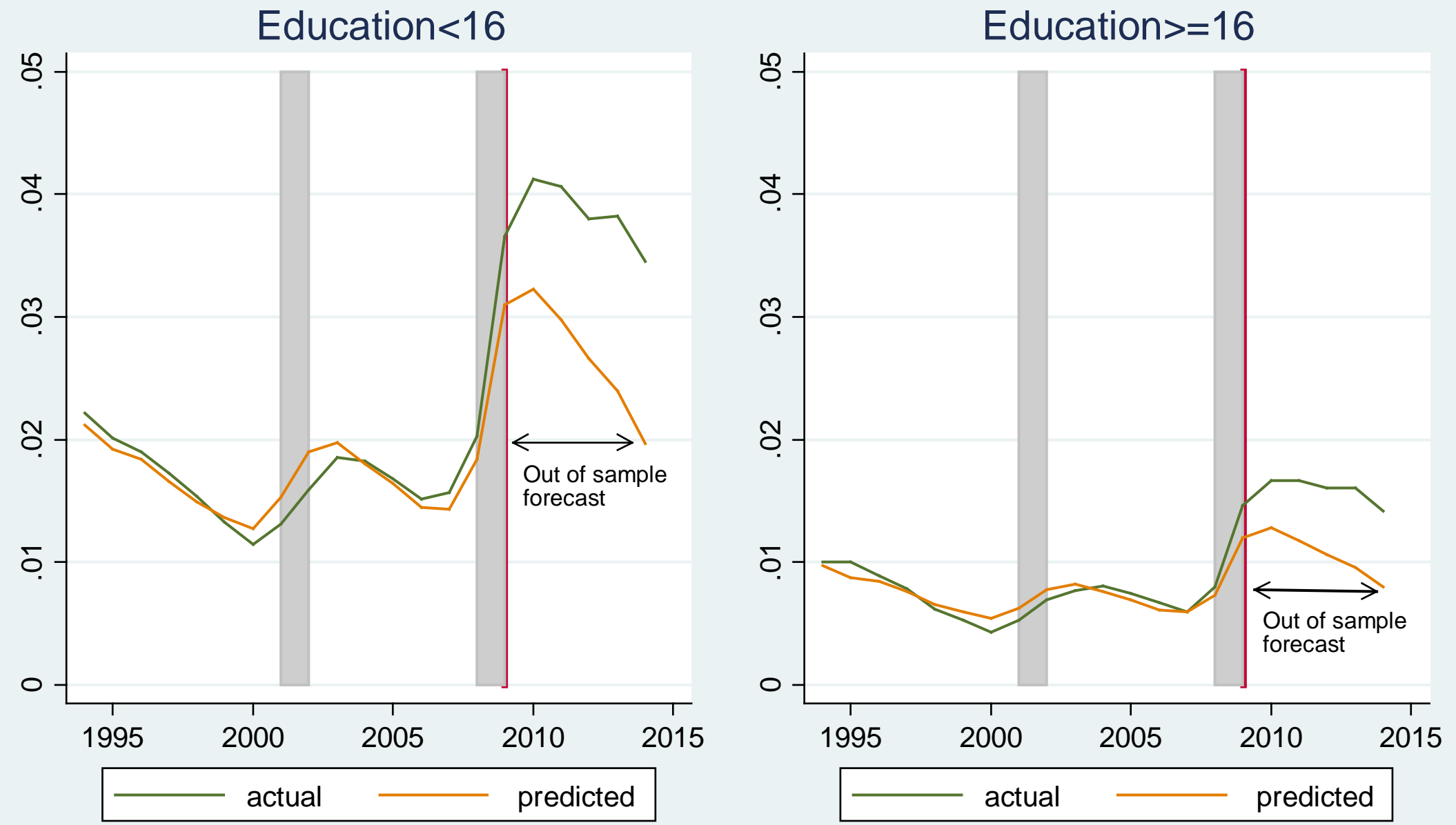

Predictions are based on a linear probability model using data from 1994-2009 controlling for economic conditions, industry,occupation, and personal characteristics of workers. Monthly predictions are converted to annual averages. 


\section{Figure 3: Proportion of Workers Affected by Occupation}
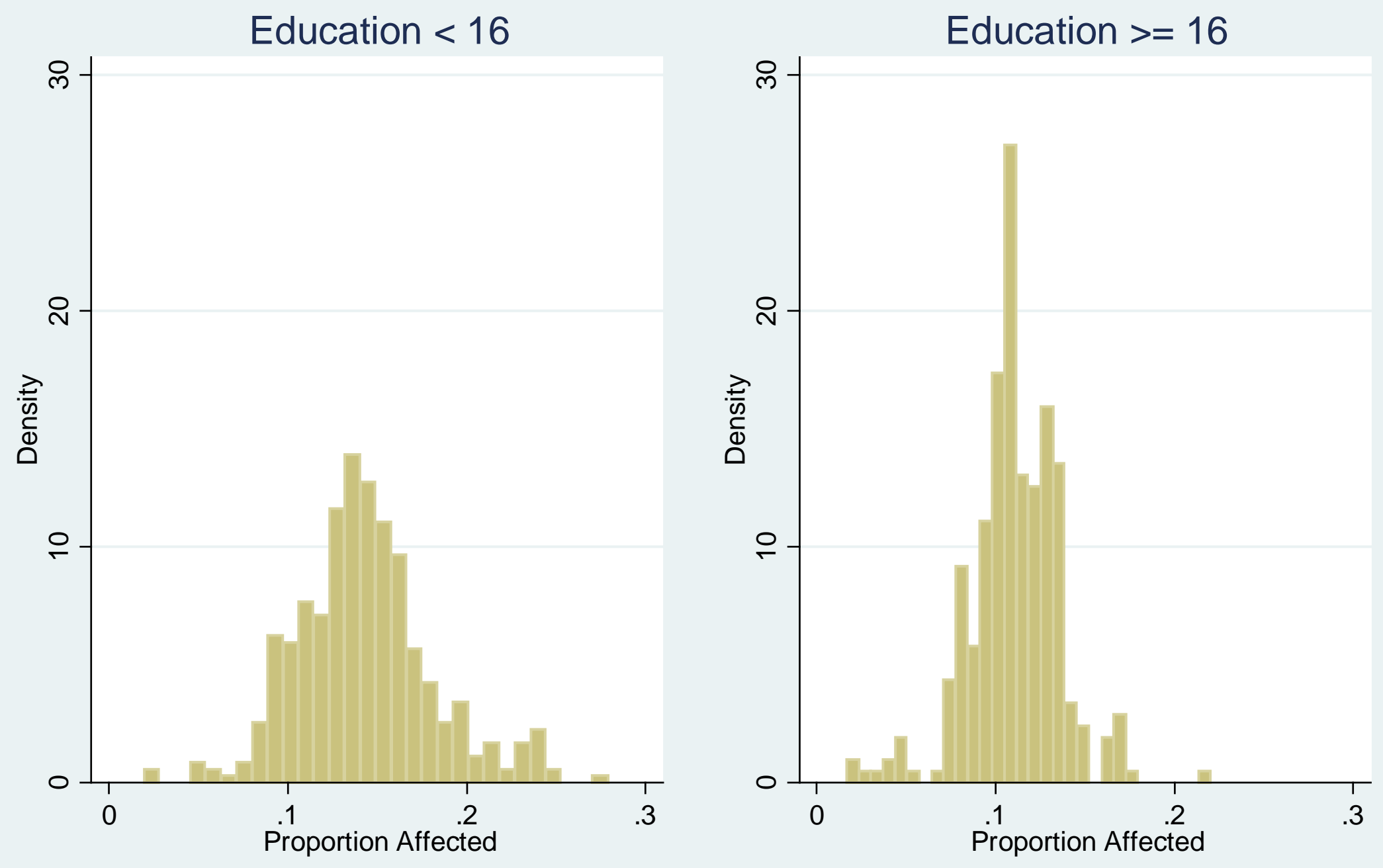

Employment weighted mean proportion affected is .160 for education $<16$ and .114 for education $>=16$. 


\section{Figure 4}

\section{Effect of ACA on Involuntary Part-Time Employment.}
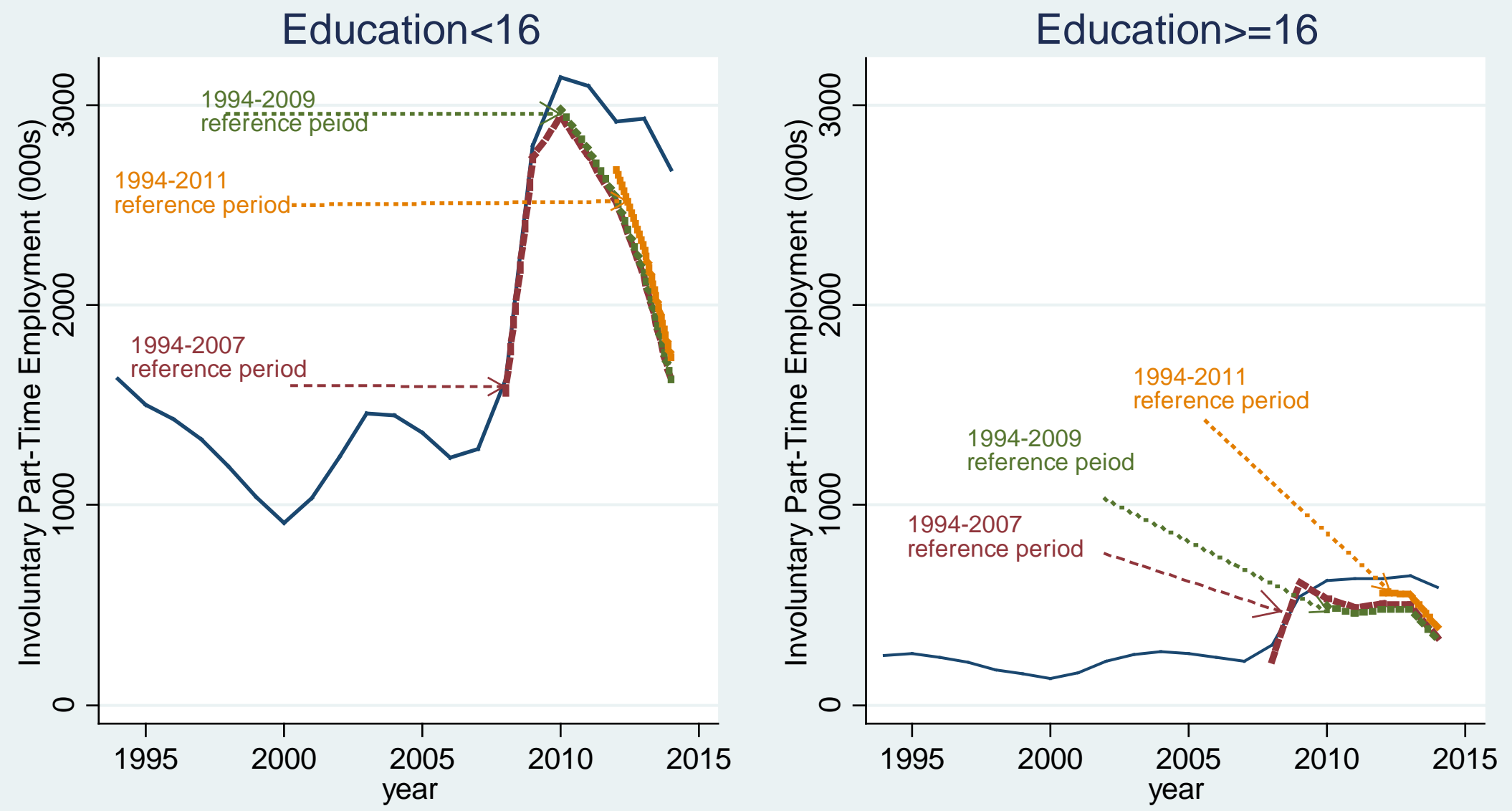

The counterfactual levels of involuntary part-time employment (IPT) without the ACA is estimated using models from table 6 to calculate the change in IPT that would result if the fraction affected in each occupation changed from actual values to zero. The 3 different counterfactuals are based on 3 different reference periods. 
Appendix 
Table A1. Determinants of Involuntary Part-Time Employment Excluding Those Working Exactly 30 hours

\begin{tabular}{|c|c|c|c|c|}
\hline \multirow[b]{2}{*}{ Year dummies } & \multicolumn{2}{|c|}{$\begin{array}{c}\text { Less than } 16 \text { years of } \\
\text { education }\end{array}$} & \multicolumn{2}{|c|}{$\begin{array}{c}16 \text { or more years of } \\
\text { education }\end{array}$} \\
\hline & & & & \\
\hline \multirow[t]{2}{*}{2010} & -0.006 & -0.006 & -0.001 & -0.001 \\
\hline & $(-1.74)$ & $(-0.83)$ & $(-0.51)$ & $(-0.55)$ \\
\hline \multirow[t]{2}{*}{2011} & -0.008 & -0.007 & -0.004 & 0.000 \\
\hline & $(-1.71)$ & $(-0.99)$ & $(-1.94)$ & $(0.17)$ \\
\hline \multirow[t]{2}{*}{2012} & -0.011 & -0.008 & -0.005 & 0.003 \\
\hline & $(-2.44)$ & $(-1.58)$ & $(-2.08)$ & $(1.04)$ \\
\hline \multirow[t]{2}{*}{2013} & -0.016 & -0.010 & -0.001 & 0.001 \\
\hline & $(-2.68)$ & $(-1.69)$ & $(-0.29)$ & $(0.50)$ \\
\hline \multirow[t]{2}{*}{2014} & -0.018 & -0.012 & -0.004 & -0.001 \\
\hline & $(-2.96)$ & $(-1.68)$ & $(-1.51)$ & $(-0.42)$ \\
\hline \multirow[t]{2}{*}{ Fraction Affected } & 0.063 & 0.023 & 0.008 & 0.070 \\
\hline & $(0.60)$ & $(0.21)$ & $(0.16)$ & $(1.08)$ \\
\hline \multicolumn{5}{|c|}{ Year dummies interacted with fraction affected } \\
\hline \multirow[t]{2}{*}{$2010 *$ Affected } & 0.068 & 0.073 & 0.013 & 0.016 \\
\hline & $(2.68)$ & $(1.62)$ & $(0.56)$ & $(0.94)$ \\
\hline \multirow[t]{2}{*}{$2011 *$ Affected } & 0.096 & 0.095 & 0.047 & 0.011 \\
\hline & $(3.30)$ & $(2.05)$ & $(2.39)$ & $(0.53)$ \\
\hline \multirow[t]{2}{*}{$2012 *$ Affected } & 0.130 & 0.111 & 0.062 & 0.001 \\
\hline & $(3.91)$ & $(3.07)$ & $(2.74)$ & $(0.07)$ \\
\hline \multirow[t]{2}{*}{$2013 *$ Affected } & 0.175 & 0.135 & 0.017 & 0.008 \\
\hline & $(3.95)$ & (3.09) & $(0.52)$ & $(0.34)$ \\
\hline \multirow[t]{2}{*}{$2014 *$ Affected } & 0.192 & 0.156 & 0.046 & 0.035 \\
\hline & $(4.31)$ & $(2.90)$ & $(1.96)$ & $(1.37)$ \\
\hline \multirow[t]{2}{*}{ Unemployment rate/100 } & -0.212 & 0.239 & -0.131 & 0.062 \\
\hline & $(-1.78)$ & $(1.44)$ & $(-1.71)$ & $(0.66)$ \\
\hline \multirow[t]{2}{*}{ Coincident index/100 } & 0.011 & 0.006 & 0.007 & 0.002 \\
\hline & $(2.08)$ & $(1.56)$ & $(1.62)$ & $(0.75)$ \\
\hline \multirow[t]{2}{*}{ Leading Index /100 } & 0.034 & 0.014 & -0.010 & 0.019 \\
\hline & $(0.89)$ & $(0.20)$ & $(-0.35)$ & $(0.44)$ \\
\hline Fraction affected estimated by & Occupation & Industry & Occupation & Industry \\
\hline $\mathrm{R}^{2}$ & 0.032 & 0.030 & 0.008 & 0.009 \\
\hline Sample size & \multicolumn{2}{|c|}{$8,475,646$} & \multicolumn{2}{|c|}{$3,703,465$} \\
\hline
\end{tabular}


Table A2. Estimated Increase in Involuntary Part-Time Employment with Alternative Reference Periods.

Reference period $1994-2007$

1994-2009

1994-2011

$\leq 16$ years of education

2008

75.5

2009

57.5

2010

194.2

156.1

2011

352.2

319.8

2012

404.7

378.8

240.3

2013

787.8

764.9

639.6

2014

$1,069.0$

$1,056.5$

951.2

2010-2014 change

874.8

900.4

16 or more years of education

2008

75.1

2009

$-72.2$

2010

90.3

126.5

2011

145.6

176.8

2012

126.6

154.8

70.5

2013

148.2

168.9

95.8

2014

252.6

265.5

162.3 139.0

200.3

2010-2014 change

--

Note: These results are based on a replication of the methodology used in table 7 but with different reference periods for estimating the increase in IPT. All employment estimates are in 1000s. 
Table A3. The Effect of Proportion Affected, Routine Task Index, and Hourly Wage on Growth in Involuntary Part-Time Employment.

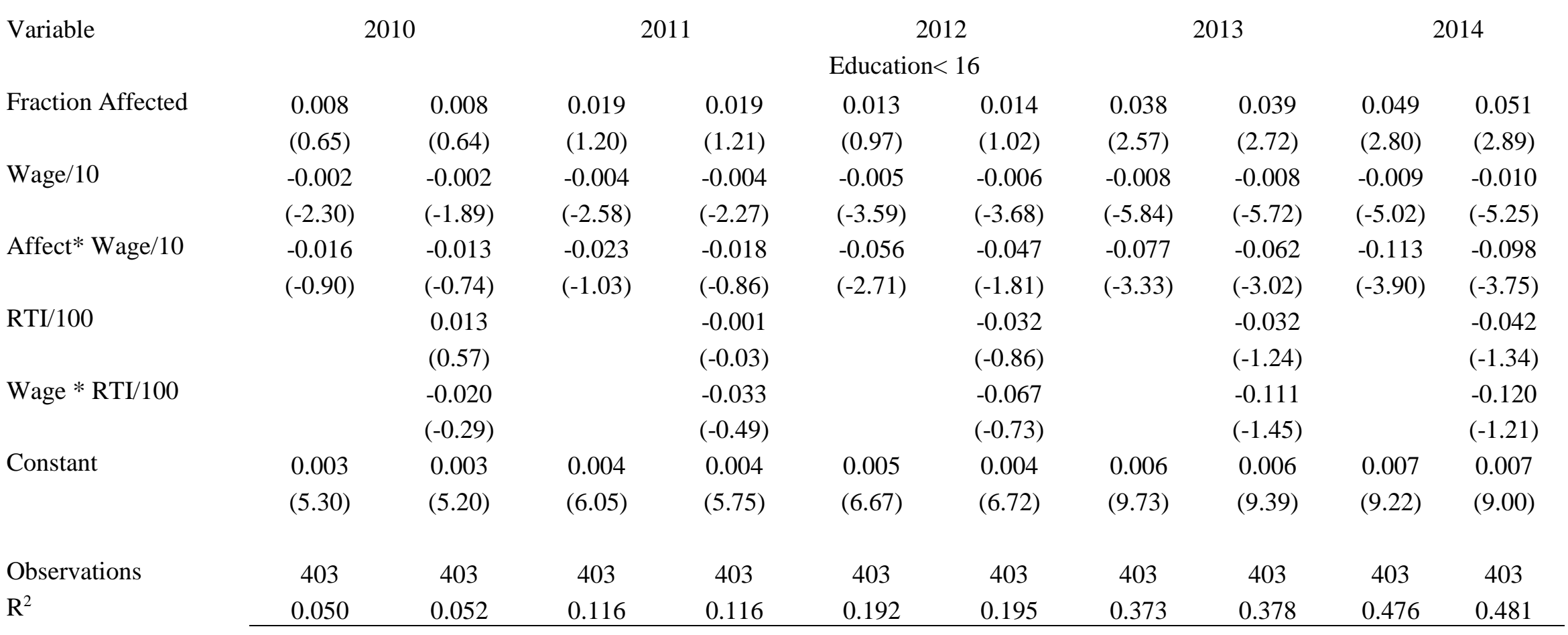




\begin{tabular}{|c|c|c|c|c|c|c|c|c|c|c|}
\hline \multirow{3}{*}{$\begin{array}{l}\text { Variable } \\
\text { Fraction Affected }\end{array}$} & \multirow{2}{*}{\multicolumn{2}{|c|}{2010}} & \multicolumn{2}{|c|}{2011} & \multicolumn{2}{|c|}{2012} & \multicolumn{2}{|c|}{2013} & \multicolumn{2}{|c|}{2014} \\
\hline & & & & & ucation> & & & & & \\
\hline & $\begin{array}{l}0.028 \\
(1.63)\end{array}$ & $\begin{array}{l}0.029 \\
(1.53)\end{array}$ & $\begin{array}{l}0.045 \\
(2.08)\end{array}$ & $\begin{array}{l}0.049 \\
(2.38)\end{array}$ & $\begin{array}{l}0.050 \\
(2.45)\end{array}$ & $\begin{array}{l}0.047 \\
(2.02)\end{array}$ & $\begin{array}{l}0.046 \\
(2.52)\end{array}$ & $\begin{array}{l}0.060 \\
(2.83)\end{array}$ & $\begin{array}{l}0.069 \\
(3.24)\end{array}$ & $\begin{array}{l}0.085 \\
(3.35)\end{array}$ \\
\hline Wage/10 & $\begin{array}{l}0.000 \\
(0.01)\end{array}$ & $\begin{array}{l}-0.000 \\
(-0.02)\end{array}$ & $\begin{array}{l}-0.002 \\
(-2.43)\end{array}$ & $\begin{array}{l}-0.004 \\
(-2.19)\end{array}$ & $\begin{array}{l}-0.001 \\
(-1.15)\end{array}$ & $\begin{array}{l}-0.005 \\
(-2.86)\end{array}$ & $\begin{array}{l}-0.004 \\
(-4.29)\end{array}$ & $\begin{array}{l}-0.005 \\
(-3.98)\end{array}$ & $\begin{array}{l}-0.005 \\
(-4.78)\end{array}$ & $\begin{array}{l}-0.008 \\
(-5.01)\end{array}$ \\
\hline Affect* Wage/10 & $\begin{array}{l}0.007 \\
(0.48)\end{array}$ & $\begin{array}{l}0.019 \\
(0.70)\end{array}$ & $\begin{array}{l}-0.018 \\
(-0.81)\end{array}$ & $\begin{array}{l}-0.025 \\
(-0.68)\end{array}$ & $\begin{array}{l}-0.011 \\
(-0.50)\end{array}$ & $\begin{array}{l}-0.010 \\
(-0.30)\end{array}$ & $\begin{array}{l}-0.039 \\
(-2.07)\end{array}$ & $\begin{array}{l}-0.018 \\
(-0.60)\end{array}$ & $\begin{array}{l}-0.053 \\
(-2.16)\end{array}$ & $\begin{array}{l}-0.049 \\
(-1.52)\end{array}$ \\
\hline RTI/100 & & $\begin{array}{l}0.007 \\
(0.22)\end{array}$ & & $\begin{array}{l}0.022 \\
(0.54)\end{array}$ & & $\begin{array}{l}0.006 \\
(0.16)\end{array}$ & & $\begin{array}{l}0.039 \\
(0.75)\end{array}$ & & $\begin{array}{c}0.046 \\
(1.10)\end{array}$ \\
\hline Wage * RTI/100 & & $\begin{array}{l}-0.035 \\
(-0.45)\end{array}$ & & $\begin{array}{l}-0.099 \\
(-1.14)\end{array}$ & & $\begin{array}{l}-0.127 \\
(-1.50)\end{array}$ & & $\begin{array}{l}-0.148 \\
(-1.64)\end{array}$ & & $\begin{array}{l}-0.254 \\
(-3.02)\end{array}$ \\
\hline Constant & $\begin{array}{l}0.001 \\
(2.24)\end{array}$ & $\begin{array}{l}0.001 \\
(2.21)\end{array}$ & $\begin{array}{l}0.004 \\
(4.37)\end{array}$ & $\begin{array}{l}0.003 \\
(4.16)\end{array}$ & $\begin{array}{l}0.002 \\
(2.21)\end{array}$ & $\begin{array}{l}0.004 \\
(5.15)\end{array}$ & $\begin{array}{l}0.006 \\
(5.55)\end{array}$ & $\begin{array}{l}0.006 \\
(6.14)\end{array}$ & $\begin{array}{l}0.006 \\
(6.67)\end{array}$ & $\begin{array}{c}0.006 \\
(7.07)\end{array}$ \\
\hline Observations & 297 & 297 & 297 & 297 & 297 & 297 & 297 & 297 & 297 & 297 \\
\hline $\mathrm{R}^{2}$ & 0.0107 & 0.0138 & 0.0612 & 0.0679 & 0.0834 & 0.0803 & 0.152 & 0.147 & 0.195 & 0.228 \\
\hline
\end{tabular}

Note: Identical to regressions in table 6 examining increase in occupation-specific probability of involuntary part-time employment with an additional control for occupation-specific measure of routine task index (RTI) and its interaction with fraction affected by ACA. The fraction affected, occupationspecific wage, and RTI are all measured as deviations from means. 